
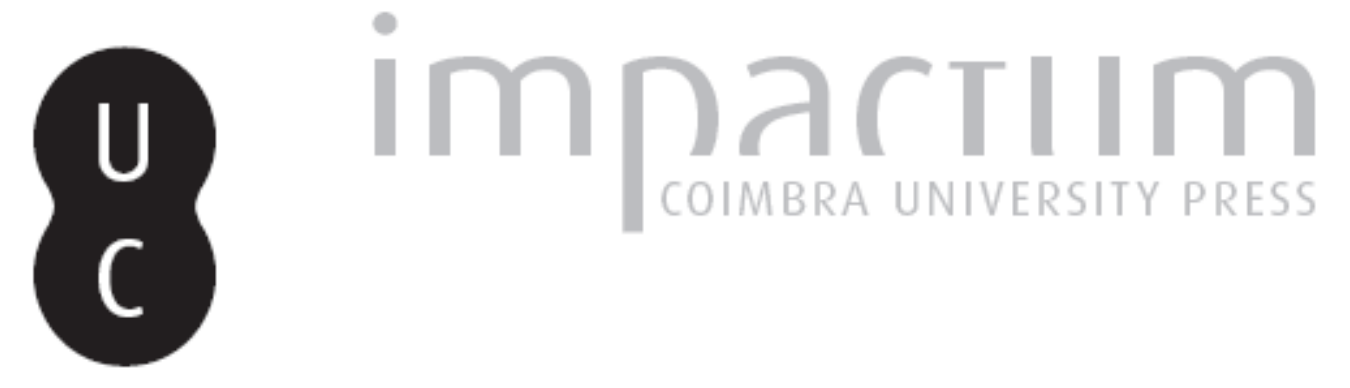

\title{
Novos rumos da Historiografia, ao longo do século XX: a História na Faculdade de Letras da Universidade de Coimbra
}

Autor(es): $\quad$ Mendes, José Amado

Publicado por: Faculdade de Letras da Universidade de Coimbra

URL persistente:

URI:http://hdl.handle.net/10316.2/32388

DOI:

DOI:http://dx.doi.org/10.14195/0870-4112_9_3

Accessed : $\quad$ 26-Apr-2023 16:08:17

A navegação consulta e descarregamento dos títulos inseridos nas Bibliotecas Digitais UC Digitalis, UC Pombalina e UC Impactum, pressupõem a aceitação plena e sem reservas dos Termos e Condições de Uso destas Bibliotecas Digitais, disponíveis em https://digitalis.uc.pt/pt-pt/termos.

Conforme exposto nos referidos Termos e Condições de Uso, o descarregamento de títulos de acesso restrito requer uma licença válida de autorização devendo o utilizador aceder ao(s) documento(s) a partir de um endereço de IP da instituição detentora da supramencionada licença.

Ao utilizador é apenas permitido o descarregamento para uso pessoal, pelo que o emprego do(s) título(s) descarregado(s) para outro fim, designadamente comercial, carece de autorização do respetivo autor ou editor da obra.

Na medida em que todas as obras da UC Digitalis se encontram protegidas pelo Código do Direito de Autor e Direitos Conexos e demais legislação aplicável, toda a cópia, parcial ou total, deste documento, nos casos em que é legalmente admitida, deverá conter ou fazer-se acompanhar por este aviso.

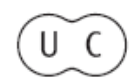



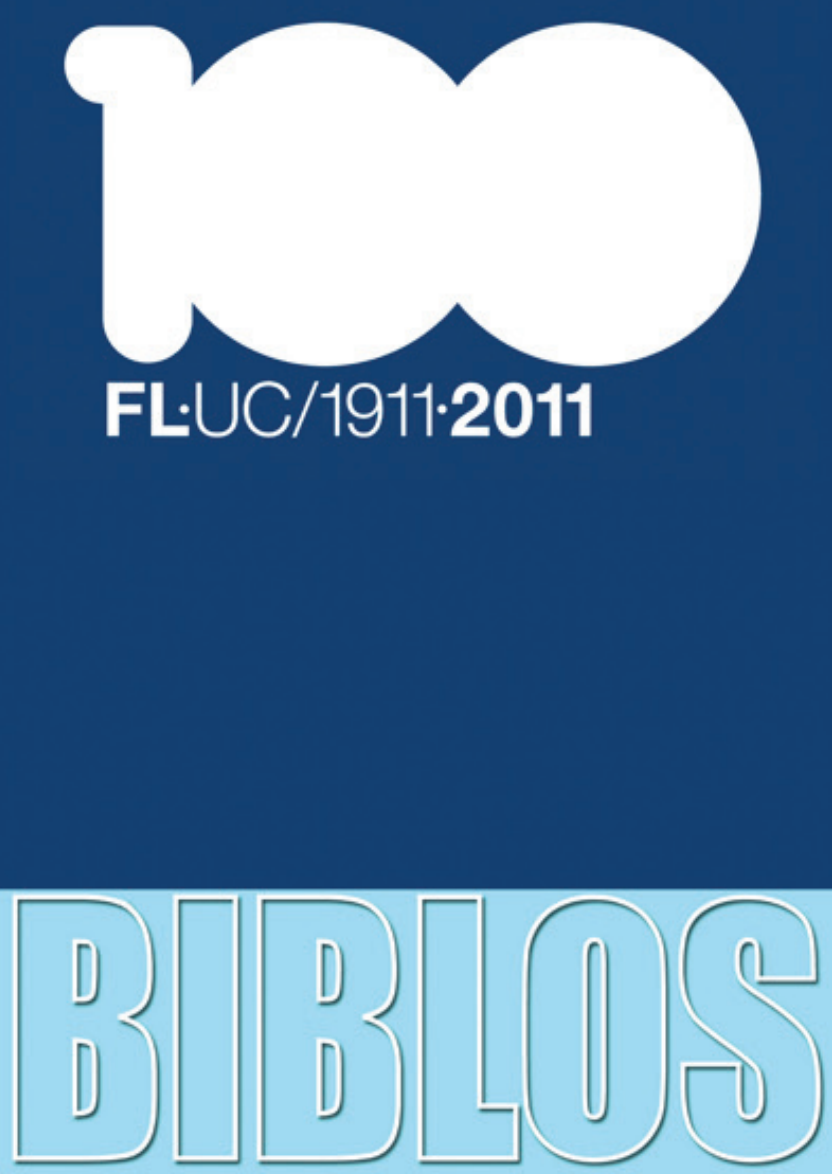

REVISTA DA FACULDADE DE LETRAS UNIVERSIDADE DE COIMBRA 


\title{
NOVOS RUMOS DA HISTORIOGRAFIA,AO LONGO DO SÉCULO XX - A HISTÓRIA NA FACULDADE DE LETRAS DA UNIVERSIDADE DE COIMBRA**
}

\begin{abstract}
Resumo
No presente texto passa-se em revista os progressos registados no último século, no que se refere às ciências históricas e à historiografia. As principais escolas históricas e as tendências historiográficas merecem especial atenção, sem perder de vista que também elas são reflexo de políticas e ideologias, da evolução cultural, social e económica da sociedade. Além dos historiadores - protagonistas do processo -, dedica-se alguma atenção a outros cientistas sociais, cujos contributos não devem ser esquecidos. Faz-se ainda uma reflexão, sucinta mas abrangente, acerca da evolução da história na Faculdade de Letras da Universidade de Coimbra, analisando: reformas, legislação, enquadramento político e institucional, ensino-aprendizagem e investigação, produção historiográfica, cursos, disciplinas e o modo como a tradição e a inovação foram convivendo, no período em análise. Deu-se o devido relevo ao período inicial - que deixou as suas marcas, durante longo tempo - e aos seguintes, uns mais apagados e outros mais dinâmicos, de acordo com o respectivo contexto, interno e externo.
\end{abstract}

Palavras-Chave: História, Historiografia, Ensino, Investigação, Escola histórica, Ideologia, Tradição, Inovação.

\begin{abstract}
This text aims to review the progress made over the past century in the historical sciences and historiography. It pays special attention to the main historiographical schools and trends, without losing sight of the fact that schools and trends are themselves a reflection of policies and ideologies, of cultural evolution and of economic developments in society.

* Professor aposentado.

** O texto que ora se apresenta, ampliado, revisto e anotado, serviu de base à exposição efectuada na Faculdade de Letras da Universidade de Coimbra, em 6 de Janeiro de 2011, integrada no ciclo de conferências promovias no âmbito das comemorações do centenário da Faculdade (1911-2011).
\end{abstract}


In addition to the historians - the protagonists of the process - some thought is given to other social scientists, whose contributions must not be forgotten. The development of history at the Faculty of Arts and Humanities is also referred to briefly yet comprehensively, by passing in review reforms, legislation, the political and institutional framework, teaching and research, historiographical production, courses, disciplines, and the way tradition and innovation coexisted during the period under analysis. Due attention is given to the initial period - which left a longlasting mark - and to the subsequent periods, some of which were more dynamic than others, depending on the internal and external context.:

Keywords: History, Historiography, Education, Research, Historiographical school, Ideology, Tradition, Innovation. 


\section{Introdução}

A história e a historiografia sofreram grandes transformações ao longo do século XX, sob diversos pontos de vista. Por um lado, verificou-se a deslocação do enfoque de temáticas dos domínios político, militar, diplomático e das elites tradicionais, para se invadir praticamente tudo o que se relaciona com a evolução do Homem em sociedade, desde a produção ao consumo, das empresas aos empresários, dos técnicos aos operários, do trabalho e do quotidiano à alimentação, das mulheres e dos estudos de género aos grupos étnicos, do vestuário à sexualidade, dos conflitos sociais aos costumes e às mentalidades, da tecnologia à ecologia, para dar apenas alguns exemplos. Por outro lado, passou a recorre-se a diversos tipos de fontes, ultrapassando-se a chamada "escravatura" das fontes escritas. Começaram a valoriza-se, igualmente, testemunhos materiais e orais, imprensa, vestígios de toda a ordem e, inclusive, o próprio "silêncio" das fontes.

Em simultâneo com o surgimento de novas especializações, a história muito beneficiou do contributo de outras áreas do saber - filosofia, sociologia, geografia, economia, estatística, etnologia e antropologia, entre outras -, bem como da colaboração dos respectivos investigadores. A teoria e a filosofia da história e a interpretação de factos e da acção dos intervenientes no processo histórico, segundo novas perspectivas e em conjunturas sociais, culturais e económicas diversas - com a marca evidente do seu tempo -, têm levado à descoberta ou à reinterpretação de novas realidades históricas, enriquecendo o nosso conhecimento do passado.

Embora certas características sejam transversais a várias escolas ou movimentos, alguns destes destacaram-se pelo facto de adoptarem metodologias e estratégias de investigação específicas, contribuindo, assim, para o avanço das ciências históricas. Recordem-se, entre outras correntes: história metódica e história positivista; materialismo histórico, nova história e escola dos "Annales", nova história económica, história narrativa, história virtual e história do presente.

Estes movimentos se, por um lado, assimilaram e incorporaram contributos da historiografia que os precedeu, acumulando experiências anteriores, por outro, enveredaram por perspectivas e metodologias inovadoras, com resultados significativos na pesquisa histórica e que, de forma explícita ou implícita, constituem um legado relevante para a 
história que fazemos, no século XXI. Visto continuarmos a beneficiar desse património - ainda que, por vezes, apenas de forma implícita e nem sempre consciencializada -, é fundamental conhecê-lo, estudá-lo e divulgá-lo, até para não considerarmos totalmente "inovadoras" perspectivas e metodologias que antecessores nossos já puseram em prática, ainda que, em muitos casos, de forma incipiente.

\section{Novos Rumos da Historiografia (Séc. XX)}

\section{Escolas, movimentos e tendências historiográficas}

As bases científicas da história foram lançadas no século XIX. A primeira cadeira de história surge na Alemanha em 1804; no entanto, um certo profissionalismo da investigação data apenas dos anos 1820-30, graças a acção de Leopold von Ranke que, nos seus seminários na Universidade de Berlim, apresentava os resultados da sua investigação e ensinava a metodologia de explorar devidamente as fontes, aprofundando a pesquisa arquivística. Na Grã-Bretanha, a história foi introduzia nos curricula universitários na década de 1850, mas sem o aperfeiçoamento metodológico introduzido por Ranke ${ }^{1}$. Nos seminários deste historiador, «os estudantes apresentavam a sua investigação e eram interrogados acerca dos métodos e especialmente sobre a exploração das fontes, que deveriam utilizar com grande cepticismo. A finalidade era treiná-los para usarem elevados níveis de rigor, no questionário a aplicar às próprias fontes» ${ }^{2}$.

$\mathrm{O}$ rigor da pesquisa arquivística e a valorização quase obsessiva das fontes levaram ao surgimento da chamada história metódica - por vezes erradamente designada positivista -, à qual esteve ligada La Revue Historique, fundada em França, em 1876, e que teve, como uma espécie de "bíblia", a obra de Charles-Victor Langlois e Charles Seignobos, Introduction aux études historiques (1898). Como destacou Henri-I. Marrou, para aqueles autores, «a história aparece como o conjunto dos factos que se extraem dos documentos; ela existe latente, mas já é real,

${ }^{1}$ CAINE, Barbara, Biography and history, Houndmills-Basingstoke, 2010, p. 14-15.

${ }^{2}$ CAINE, op. cit., p. 14. 
nos documentos, mesmo antes de intervir o trabalho do historiador» ${ }^{3}$. Uma das máximas desta escola era a seguinte: "os documentos falam por si".

Muito diferente daquela é a história positivista, que sofreu grande influência da sociologia de Augusto Comte e que atribuía um papel mais relevante ao historiador, a quem compete «compreender manifestamente a universalidade dos factos que a razão dirige ou dos quais sofre influência». Louis Bordeau, discípulo de Comte, define os princípios desta escola, na obra intitulada Histoire et historiens. Essai critique sur l'histoire considerée comme science positive (1888).

No final de Oitocentos e primeiras três décadas do século XX, a história, que continuou a registar relevantes progressos, passou igualmente a beneficiar do contributo de outras disciplinas. Por exemplo, ainda no que concerne à sociologia - além da sua marca profunda na história positivista -, deve sublinhar-se a importância da obra dos sociólogos e economistas alemães, Werner Sombart (1863-1941) e Max Weber (1864-1920). Este último autor, no seu conhecido livro A Ética Protestante e o espírito do capitalismo - trabalho importante, ainda que controverso -, num rasgo de inovação apreciável, ligou religião e economia ou, como também já se afirmou, «a evolução do capitalismo ocidental à cultura ${ }^{4}$. Também a geografia, através de Vidal de la Blache (1845-1918) - fundador da "escola possibililista de geografia" - e de outros autores, muito contribuiu para moderar ou mesmo contrariar o determinismo geográfico de Friedrich Ratzel (1844-1904), tendo influenciado, por exemplo, Lucien Febvre (1878-1956), March Bloch (1868-1944) e Fernand Braudel (1902-1985).

Para estes autores, o condicionalismo geográfico apenas disponibiliza ao homem possibilidades - que este poderá aproveitar ou não -, mas de modo algum determina a sua acção. A questão do possibilismo e das suas potencialidades foi analisada por Lucien Febvre, na obra A Terra e evolução humana. Introdução geográfica à história (1922) ${ }^{5}$.

${ }^{3}$ MARROU, H.-I, Do conhecimento histórico (trad. do francês), 2. ${ }^{a}$ ed., Lisboa, Ed. Aster, s. d., p. 47.

${ }^{4}$ FERGUSON, Niall (coord.), História Virtual (trad. do inglês), Lisboa, Tinta da China, 2006, p. 67-68.

${ }^{5}$ A obra, inicialmente publicada em 1922, teve várias edições, a 3. ${ }^{a}$ das quais em Paris, em 1949. Em 1954 viria a ser traduzida para português por Jorge Borges 
Todavia, mais significativa do que qualquer destes movimentos historiográficos foi a influência da chamada escola dos Annales, associada à revista com o mesmo nome, fundada em Estrasburgo (1929). Ao longo de cerca de quatro décadas (1930-1970), ela influenciou decisivamente a historiografia ocidental, de modo particular a dos países latino-americanos, mas não deixando também indiferentes a dos países anglo-saxónicos e mesmo a de outras áreas geográficas.

A chamada nova história ou história dos Annales caracteriza-se pela atenção redobrada que presta, entre outros, aos seguintes factores:

- diversificação das fontes e alargamento do respectivo conceito;

- estudo de séries, de preferência ao estudo de factos ou eventos isolados, permitindo o desenvolvimento da história quantitativa e o tratamento estatístico dos dados, possibilitando a detecção de tendências e a sua fácil visualização, por meio de gráficos e quadros;

- alargamento temático a esferas outrora esquecidas,de índole económica, social, psicológica e relacionadas com as mentalidades;

- partir do problema - daí também apelidar-se "história-problema" -, dando maior relevância à interpretação e construção pelo historiador, considerando as fontes apenas como matéria-prima, para a construção do "edifício" da história";

- na sua primeira fase (décadas de 1930-1960), grande relevância dada à história económica e social e ao respectivo contexto geográfico;

- valorização das várias dimensões temporais (tempo curto, médio e longo), com destaque para este último, na análise histórica. Como recorda Fernando Catroga, a representação vectorial do tempo teve uma grande relevância na cultura ocidental ${ }^{7}$.

de Macedo, com revisão de Joel Serrão, em Panorama da Geografia, vol. II, Lisboa, Cosmos, 1954, p. 411-733.

${ }^{6}$ MENDES, José M. Amado, A História como Ciência. Fontes, Metodologia

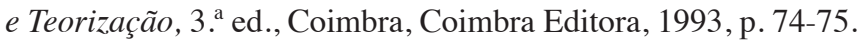

${ }^{7}$ CATROGA, Fernando, Caminhos do fim da História, Coimbra, Quarteto, 2003, p. 18. 
Têm-se dedicado vários estudos à escola dos Annales (FORSTER ${ }^{8}$, BURGUIÈRE ${ }^{9}$, BOURDÉ e MARTIN ${ }^{10}$ e REVEL ${ }^{11}$ ), pelo que não desenvolverei aqui o assunto. Apenas direi que aquela, pelo menos na sua primeira fase, foi acentuadamente inovadora, embora também se lhe pudessem apontar algumas limitações. Por exemplo, Josep Fontana i Làzaro, num interessante artigo, intitulado «Ascenção e decadência da Escola dos “Annales» (1979), não obstante reconhecer o muito que devia aos historiadores identificados com a referida escola - Marc Bloch, Fernand Braudel e outros -, também critica a sua produção histórica, sublinhando a ausência, na respectiva historiografia, de uma teoria global da sociedade, a relevância excessiva atribuída à geografia e à história económica e social e a secundarização da história política, concluindo o seu estudo do seguinte modo: «Desenvolvemos o nosso sentido crítico através da leitura dos Combats pour l'histoire [1953] de Lucien Febvre e devemos a Braudel o ter-nos aberto os olhos para perspectivas muito mais amplas do que as que eram habituais nos nossos meios académicos. Mas isto não nos deve impedir de perceber que a hora da escola dos Annales já passou, que o impulso inovador que comunicou à investigação histórica europeia já se esgotou. Segui-los, na sua obsessão ecléctica de modernidade, no seu neopositivismo que confunde método e teoria e mitifica o papel do instrumento, seria perigoso. $\mathrm{O}$ axioma é velho, mas continua a ser válido: "sem teoria não há história"» ${ }^{12}$.

É óbvio que o autor, ao fazer aquelas críticas, tinha presentes outras propostas historiográficas que entretanto haviam surgido e que, já na altura, contavam com cerca de duas décadas de experiência. Com efeito, por meados do século XX, surge - primeiro nos Estados Unidos da América e, posteriormente, no Reino Unido - uma outra corrente,

${ }^{8}$ FORSTER, Robert, «Achivementes of the Annales School», The Journal of Economic History, vol. XXXVIII, n. ${ }^{\circ}$ 1, 1978, p. 58-76.

9 BURGUIËRE, André, «Histoire et structures». «Introduction», Annales. E.S.C., n. ${ }^{\circ} 3-4,1973$.

${ }^{10}$ BOURDÉ, Guy e MARTIN, Ervé, Les écoles historiques, Paris, Ed. do Seuil, The Free Press, 1983.

${ }^{11}$ REVEL, Jacques, «Histoire et Sciences Sociales: les paradigmes des Annales», Annales. E. S. C., 34. ${ }^{\circ}$ ano, n..$^{\circ}$ 61, 1991, p. 1360-1366.

${ }^{12}$ LÀZARO, Josep Fontana i, "Ascensão e decadência da Escola dos “Annales"», Histórias \& Ideias, vol. I, n. . 3-4, 1979, p. 65-79. 
designada nova história económica, cujo principal meio de divulgação tem sido The Journal of Economic History (publicado, continuamente, desde 1940). Em virtude do relevo dado pelos seus cultores à quantificação e à medição, outras designações lhe foram atribuídas: escola ou história cliométrica; cliometria e história econométrica ou, de acordo com a sua origem, em inglês, new economic history. Esta corrente distingue-se, fundamentalmente, pelo seguinte: a) aplicação da teoria económica à investigação histórica; b) procura combinar teoria e factos; c) trata-se de uma teoria aplicada, recorrendo à utilização de modelos e do contrafactual, isto é, o estudo de uma temática, isolando explícita e deliberadamente uma variável, a fim de avaliar, com mais objectividade, qual o seu peso no respectivo contex to ${ }^{13}$.Voltarei, entretanto, ao assunto.

Obviamente que outras correntes de pensamento - como o marxismo, o materialismo histórico, o estruturalismo, o historicismo ou o pós-modernismo ${ }^{14}$ - também exerceram a sua influência nas escolas ou tendências historiográficas, na filosofia e na teoria da história, na perspectiva ou nos conceitos frequentemente usados; recordo, entre outros: estrutura e infra-estrutura, análise sistémica e história global e história total, forças produtivas, força de trabalho, capital e mais-valia.

Apesar de não se tratar, propriamente, de escolas mas sim de tendências, pelos anos 1960-1970, tanto dentro da própria corrente dos Annales como no âmbito de outros movimentos, a história económica e social e a história serial começaram a perder terreno, em favor de novas temáticas, mais diversificadas e ligadas a outros domínios da realidade. Passa, assim, a dedicar-se mais atenção e a investigarem-se novos assuntos, por um lado, da esfera das mentalidades e das ideias, das representações, dos costumes, da crença e da morte (movimento no qual a chamada " 2 . ' geração dos Annales" também participou) e, por outro, do âmbito do quotidiano, como a habitação e a alimentação, as "coisas banais" 15 o trabalho, a tecnologia, a sexualidade, a marginalidade e a vida privada, entre outros.

\footnotetext{
${ }^{13}$ MENDES, op. cit., p. 79-80.

${ }^{14}$ MUNSLOW, Alun, The future of history, Inglaterra-Estados Unidos, Palgrave Macmillan, 2010, p. 25.

${ }^{15}$ Daniel Roche, História das coisas banais. Nascimento do consumo nas sociedades tradicionais, Sécs. XVII-XIX (trad. do francês), Lisboa, Ed. Teorma, 1998.
} 
Ao invés do que sucedia até então - em que a análise macro era privilegiada - , tanto relativamente a pessoas como a fenómenos ou eventos, já que indivíduos ou factos isolados não se harmonizam com a generalidade a que a ciência aspira -, passaram a contemplar-se, mais frequentemente, factos únicos ou personalidades, através de estudos biográficos ou prosopográficos.

\section{Forma e metodologia}

Do ponto de vista da forma - temática constante na actividade do historiador, ainda que não sempre explicitada -, a questão adquiriu nova relevância, desde o final dos anos 1970, com o alerta lançado pelo historiador inglês Lawrence Stone, ao apelar ao regresso à narrativa ${ }^{16}$. Esta questão, embora à primeira vista não pareça, tem implicações mais vastas, por se ligar a outras da maior importância e sobre as quais os historiadores, desde há muito, se interrogam: devem aplicar-se, à história, formas literárias? A história é uma arte ou uma ciência? Ou é uma e outra coisa? No fundo, uma questão, tão querida à "velha história", salta assim para a ordem do dia da "nova história". E não é a única, como mostrou Gertrude Himmelfarb, na obra A velha história e a nova (1987). Segundo esta historiadora norte-americana, nem a nova história é tão nova como se diz, nem a velha está tão desactualizada como se apregoa.

A propósito do regresso à narrativa, já foi sublinhado: «O renascimento da narrativa mostra-nos, portanto, as duas faces de Janus: por um lado, um renascimento do interesse pelos modelos literários tradicionais para a escrita da história e, por outro, um influxo da terminologia da moda (desconstrução textual, semiótica e assim por diante), na sua leitura. O pós-modernismo atingiu a história, mesmo que os pós-modernistas se limitem a apresentar velhas panaceias idealistas, quando declaram que a história é "uma prática interpretativa e não uma ciência objectiva neutral"» ${ }^{17}$.

${ }^{16}$ STONE, Lawrence, «The Revival of Narrative: Reflections on a New Old History?», Past and Present, n. ${ }^{\circ} 85,1979$, p. 3-24.

${ }^{17}$ FERGUSON, op. cit., 76. 
Relativamente à metodologia, merece destaque a chamada história virtual, que também tem vindo a adquirir, ultimamente, maior visibilidade. Esta perspectiva de análise começou a aplicar-se nos Estados Unidos da América, especialmente no âmbito da já referida nova história económica. Como disse já, para os cliométricos, isolar determinada variável do respectivo conjunto de que faz parte colocando-a, provisoriamente, entre parênteses, como se ela não tivesse existido - permite quantificar, de forma hipotética, o desempenho de uma economia ou de uma das suas componentes, sem o contributo daquela. A diferença de resultados, entre a realidade histórica que se conhece e a obtida no cenário imaginado, devidamente quantificada (desenvolvimento inferior em 10, 15, ou 20\%, por exemplo), corresponde ao peso que a dita variável terá tido no conjunto do processo. Trata-se de uma quantificação/medição, ainda que de forma indirecta. Posteriormente, também noutros países - Inglaterra, Espanha e, esporadicamente, em Portugal -se têm realizado ensaios, segundo aquela metodologia. Além disso, nota-se um alargamento da sua aplicação a outras modalidades de história - política, militar e diplomática -, ultrapassando as temáticas inicialmente preferidas pelos historiadores norte-americanos, quase só circunscritas à história económica (abolição da escravatura e a introdução do caminho-de-ferro nos Estados Unidos).

Como introdução à temática, é da maior utilidade a obra coordenada por Niall Ferguson, Virtual History. Alternatives and Conterfactuals $(1997)^{18}$. Numa extensa introdução - intitulada "História virtual: rumo a uma teoria do passado" -, o coordenador da obra faz o ponto da situação, tentando "demover" os mais incrédulos, que argumentam que "a história não se faz com "se"(s)" ou que defendem, como afirma E. H. Carr: "A "história contrafactual" é um mero "jogo de salão", um "beco sem saída". Sob este ponto de vista, não há nem houve duas vias possíveis e as perguntas começadas por "E se?" não merecem ser feitas. Contemplar "as coisas que poderiam ter acontecido" corresponde não apenas a subscrever a teoria do "Nariz de Cleópatra" mas também a ser um mau perdedor» ${ }^{19}$.

\footnotetext{
${ }^{18}$ Obra traduzida para português, uma década depois, apenas com o título História Virtual, Lisboa, Tinta da China, 2006.

${ }^{19}$ FERGUSON, op. cit., p. 18.
} 
O autor refuta, obviamente, esta opinião. Como sublinha - a exemplo do que tem sido feito por outros historiadores -, todos nós, ao fazermos história, admitimos, implicitamente, o contrafactual/ /virtual, só não o expressamos nem tiramos daí as devidas ilações. Ou seja, se consideramos que um evento ou a acção de uma personagem histórica foram de relevância considerável ou muito importantes, aceitamos implicitamente que, na sua ausência, a história teria sido outra. Mas, para o autor, mais decisivo ainda é o argumento a que recorre, segundo o qual, não aceitar o contrafactual é característico das teorias deterministas da história, considerando «a história virtual como um antídoto necessário contra o determinismo». E prossegue: «O mundo não foi ordenado por um ser divino, nem é governado pela Razão, pela luta de classes ou por qualquer outra "lei" determinista. Tudo o que podemos dizer com algum grau de certeza é que está condenado ao aumento da desordem por entropia. Os historiadores que estudam o passado devem sentir-se duplamente inseguros porque os artefactos que consideram provas sobreviveram, muitas vezes, por acaso e porque, ao identificar um artefacto com testemunho histórico, o historiador distorce, de imediato, o seu significado. Os acontecimentos que tentam deduzir dessas fontes foram, originalmente, "estocásticos" - por outras palavras, aparentemente caóticos -, porque o comportamento do mundo material é regido tanto por equações lineares como por equações não lineares $»^{20}$. No que respeita à possibilidade de se admitir um número infinito de bifurcações - o que constituiria uma dificuldade acrescida ,- o autor responde que «as possibilidades contrafactuais devem ser aquelas que os contemporâneos contemplaram $»^{21}$. Foi esta metodologia a adoptada na referida obra, na qual são apresentados sete estudos de caso e uma conclusão.

Naqueles estudos, os autores procuram responder às seguintes questões:

- E se a Revolução Americana não tivesse acontecido?

- E se a Grã-Bretanha tivesse ficado de fora em Agosto de 1914?

- E se a Alemanha tivesse invadido a Grã-Bretanha em Maio de 1940 ?

- E se a Alemanha nazi tivesse derrotado a União Soviética?

${ }^{20}$ FERGUNSON, op . cit., 98.

${ }^{21}$ FERGUNSON, op. cit., p. 97. 
- E se a Guerra Fria tivesse sido evitada?

- E se John F. Kennedy não tivesse morrido?

- E se o comunismo não se tivesse desmoronado?

Segue-se uma conclusão, sob o título Uma história virtual 1646$-1996$.

Se desejarmos contemplar alguns exemplos, relativos à história de Portugal, aos quais se poderá adequar a metodologia da história virtual, entre muitos outros possíveis, sugiro apenas dois: e se a Família Real não se tivesse ausentado (ou fugido, segundo a tese de Oliveira Martins e de alguns outros autores) para o Brasil, em 29 de Novembro de 1807 ? E se Sá Carneiro e Adelino Amaro da Costa não tivessem falecido, no acidente de Camarate, em 4 de Dezembro de 1980?22.

Uma outra inovação recente - mas que, afinal, não é mais do que o regresso a um passado não muito distante - é a chamada história do presente. Ao contrário do que se verificava até finais do século XIX - por exemplo, em Portugal -, no século XX, foi-se interiorizando a ideia segundo a qual a história só poderia ser elaborada num período relativamente distante daquele a que dizia respeito. Alegava-se que, para períodos próximos, além de não ser possível o acesso a determinados tipos de fontes, faltava ainda perspectiva temporal e, inclusive, não se conheciam muitas das consequências dos factos/eventos em foco. Recordo, no entanto, que, há cerca de um século, a questão não se colocava, por exemplo, a Oliveira Martins, a Alberto Sampaio ${ }^{23}$ ou a Antero de Quental, para quem, nos respectivos estudos históricos, o presente convivia bem com o passado e, por esse facto, constituía igualmente objecto de estudo

Ora, ainda que os argumentos, anteriormente referidos, possam ter alguma pertinência, a diversidade de fontes a que hoje podemos recorrer e o facto de qualquer construção histórica nunca ser definitiva mas sim provisória - e, logo, contributo para posteriores estudos - fazem com que, actualmente, os historiadores tornem a voltar-se

${ }^{22}$ Acrescento que a última interrogação já foi feita, em órgãos da comunicação social, por um historiador (Rui Ramos), no jornal Público, e por um comentador (Marcelo Rebelo de Sousa), através de uma cadeia de televisão (TVI).

${ }^{23}$ MENDES, José Amado, «Alberto Sampaio, precursor da história do presente», Boletim Cultural. Vila Nova de Famalicão, 3/4, III série, 2007/8, p. 415-426. 
para a história próxima e até para a ego-história. Tratando-se de uma modalidade recente e ainda em construção, não há unanimidade, entre os historiadores, acerca da própria designação - história imediata, história recente, história actual, história do presente? -, assim como não existe concordância, relativamente ao período abrangido: último meio século? período posterior à II Guerra Mundial? anos seguintes à queda do Muro de Berlim?

Em defesa da história do presente, sublinha um autor: «Quando afirmamos que a história antes de mais se refere à dimensão tempo, com isso queremos significar que, na actualidade, esta disciplina se deve ocupar do estudo do social em todos os intervalos temporais que englobam o conceito tempo, assim como nas compenetrações de mudança que se apresentam entre os seus distintos componentes» ${ }^{24}$.

Nesta modalidade de história, são relevantes os seguintes elementos: testemunho, memória, procura social e acontecimento; tem ainda, como traços distintivos: unidade temporal entre sujeito e objecto; confluência do subjectivo e do objectivo; ponto de encontro entre jornalismo, história e literatura. Assim, o historiador - como o politólogo, o economista, o sociólogo ou o jornalista - não pode deixar de participar no estudo e na discussão de fenómenos tão pertinentes e actuais como os seguintes: choque de civilizações (S. Huntigton), fim da história (F. Fukuyama), pós-modernismo (J.-F. Lyotard) ou sociedade pós-industrial ${ }^{25}$, para dar somente alguns exemplos.

\section{Legado historiográfico, transmitido do século XX ao século XXI}

Como sucede, em muitas outras situações, o novo não substitui de imediato, radical e abruptamente, o velho. Os processos inovadores se, por vezes, se fazem por ruptura, outras concretizam-se por meio de contributos sucessivos, integrando e adaptando muito do precedente. As novas correntes historiográficas - às quais poderíamos chamar

${ }^{24}$ AROSTÉGUI, Julio, La historia vivida. Sobre la historia del presente, Madrid, Alianza Editorial, 2004, p. 9.

${ }^{25}$ MENDES, 2008, p. 417-418. 
paradigmas, usando a terminologia de T. S. $\mathrm{Kuhn}^{26}$ - surgem quando as praticadas deixam de responder às necessidades ou, por outras palavras, quando não permitem solucionar problemas novos. Assim, a "ciência normal" é substituída, total ou parcialmente, por outra, dando-se então o que se pode denominar "revolução científica".

No âmbito da historiografia, e apenas a título de exemplo, a "velha história" não se ocupava: a) dos diversos grupos sociais, mas sim das elites tradicionais, o que não se adequava com a democratização da sociedade em curso; b) do estudo das mulheres, não obstante o seu papel ser cada vez mais destacado, nas várias esferas da realidade; c) da ciência e da tecnologia, da maior importância, em nossos dias; d) do mundo empresarial, apesar da função decisiva das empresas e da sua envolvência no quotidiano, fornecendo-nos produtos e serviços de vária ordem; e) do indivíduo e do seu papel, em contradição com a comunicação social, que elege aquele como principal protagonista dos conteúdos informativos.

O modelo, aplicado por Kuhn às ciências experimentais - também por vezes designadas, ainda que menos apropriadamente, exactas -, em certa medida também se pode adequar à historiografia, embora com algumas ressalvas. Uma delas é que, enquanto nas verdadeiras revoluções científicas as alterações são tão profundas que o novo paradigma, em muitos casos, é incompatível com o antigo - isto é, o da "ciência normal" -, no domínio da história, devido ao seu carácter mais "soft", as transformações, regra geral, não são tão abruptas nem radicais. Daí que as persistências se mantenham por longos períodos, como mostrou Arno Mayer, ao detectar persistências do Antigo Regime, até ao período de entre as guerras mundiais ${ }^{27}$.

Vem isto a propósito do que ficou exposto sobre as escolas/movimentos/tendências da historiografia, de finais do século XIX aos inícios do século XXI. Com efeito, o historiador continua a basear-se em fontes (legado da história metódica e mesmo de progressos anteriores, registados nos séculos XVII a XIX), embora, hoje, o conceito de fonte seja muito mais lato (herança da escola dos Annales e da nova história).

\footnotetext{
${ }^{26}$ KUHN, Thomas S., La structure des revolutions scientifiques (trad. do inglês), Paris, Flammarion, 1972.

${ }^{27}$ MAYER, Arno J., La persistência del Antiguo Régimen. Europa hasta la Grand Guerra (trad. do inglês), Madrid, Alianza Editorial, 1981.
} 
Todavia, sabemos hoje que as fontes ainda não são história, mas sim matéria-prima, a ser tratada e aproveitada pelo historiador. Com efeito, se sem fontes não há história, também sem teoria aquela não existe (como defenderam os cultores da história positivista e da nova história económica).

Mas a história, para além de ser investigada e compreendida, é igualmente ensinada e transmitida, sob diversos meios e formas. Daí que o regresso à narrativa nos tenha recordado a importância que a forma assume, para que a sua divulgação possa cativar os interessados, e não repeli-los, por não se ter encontrado a forma adequada de a divulgar.

A história económica e social, quando se tornou mais sofisticada e incorporou um grande aparato estatístico (anos de 1930-1960) secundarizando a narrativa -, passou a destinar-se sobretudo a iniciados, afastando-se, por se ter tornado desinteressante e pouco apelativa, de um público mais vasto. A questão, hoje, torna-se ainda mais pertinente, dada a diversidade de meios de comunicação e divulgação históricas: imprensa escrita, rádio e televisão, internet, cinema e vídeos são apenas alguns exemplos.

A análise sistémica e a história global - pontos fortes do estruturalismo e da nova história - continuam a ser importantes, para atenuar uma certa proliferação das temáticas históricas, dispersas por numerosas especialidades (a história "aos bocados", como já se lhe chamou). Por seu lado, o pós-modernismo, ao chamar a atenção para o indivíduo, o único e a especificidade - que não devem ser submersos pelos fenómenos de massa -, tem contribuído, igualmente, para um regresso à biografia, falando-se já de "biographical turn"28.

Por último, ao falar-se da história do presente, quer significar-se que, em tudo o que diga respeito ao homem e à sociedade, a história - ou, melhor, o historiador - tem uma palavra a dizer, colocando o seu extraordinário desenvolvimento, alcançado no último século e meio como disciplina, ao serviço da comunidade e da cultura. Trata-se de um dever, mas igualmente de um direito. Como destacou, recentemente, um autor: «A história é mais do que aquilo que os historiadores

\footnotetext{
${ }^{28}$ CAINE, op. cit., p. 1.
} 
profissionais fazem, pois a história não é meramente um exercício académico abstracto - ela é um imperativo cultural $\gg^{29}$.

\section{A História na FLUC: tradição e inovação}

No âmbito das comemorações do centenário (1911-2011) da Faculdade de Letras da Universidade de Coimbra (FLUC), faz todo o sentido reflectir sobre a evolução dos diversos ramos de saber nela cultivados, no âmbito das Humanidades e das Ciências Sociais, ao longo do primeiro século do seu percurso com instituição. No que à História diz respeito, na impossibilidade de focar aqui o assunto com a devida profundidade e tendo presentes os contributos já disponíveis sobre a temática ${ }^{30}$, privilegiarei os aspectos mais elucidativos relacionados com a tradição e a inovação, à luz dos progressos registados no período em foco, já sumariamente analisados no ponto I.

A Faculdade de Letras, criada em $1911^{31}$, resultou da extinção da Faculdade de Teologia (que já não foi autorizada a abrir, no ano lectivo de 1910-1911), cuja procura pelos estudantes vinha a decrescer progressivamente, nos primeiros anos do séc. XX. Assim, como em 1907 o número de alunos que frequentava aquela Faculdade era apenas de 22, os professores, através de posição unânime tomada pelo Conselho, solicitaram ao governo para que a Faculdade se transformasse em Faculdade de Letras, sublinhando: «É constituída a Faculdade

${ }^{29}$ MUNSLOW, op. cit., p. 17.

${ }^{30}$ Entre outros, recordo os trabalhos de João Paulo Avelãs Nunes, sobre a história económica e social (1911-1974), e o meu, acerca da história na FLUC (1911-1926), bem como obras de carácter mais geral de, por exemplo, Luís Reis Torgal, Fernando Catroga, Amadeu Carvalho Homem, Manuel Augusto Rodrigues, Maria Helena Coelho, Maria Manuela Tavares Ribeiro e Irene Vaquinhas ou, ainda, o elevado número de obras produzidas pelos docentes e investigadores de história da Faculdade - cujos nomes, por constituírem uma extensa lista, não é possível referenciar aqui -, ao longo dos últimos cem anos.

${ }^{31}$ As Faculdades de Letras de Coimbra e Lisboa foram criadas pelo Decreto de 19 de Abril de 1911; por sua vez, o Decreto com força de Lei de 9 de Maio do mesmo ano estabeleceu a legislação orgânica das referidas Faculdades (RODRIGUES, Manuel Augusto, A Universidade de Coimbra no século XX. Actas da Faculdade de Letras, vol. I (1911-1925), Publicações do Arquivo da Universidade de Coimbra, Coimbra, 1989, p. v). 
[de Teologia] por doze professores, muitos dos quais se encontram em circunstâncias de idade e robustez próprias, quer para se aprimorarem em estudos alheios ao magistério teológico, a que até agora se haviam entregado, quer para refazerem a sua educação científica, dando novo rumo ao seu labor mental, e aptos por isso para continuarem a desempenhar no professorado superior, em outra ordem de estudos, a missão docente que na Universidade estão exercendo» ${ }^{32}$.

\section{Da Faculdade de Teologia à Faculdade de Letras (1911-1926)}

Dos doze professores pertencentes à Faculdade de Teologia, seis foram integrados na FLUC, quatro dos quais passaram a dar a sua colaboração à respectiva secção de História, designadamente: Francisco Martins (1848-1916), Augusto Joaquim Alves dos Santos (1866-1924), Porfírio António da Silva (1855-1919) e António Garcia Ribeiro de Vasconcelos (1860-1941). Não obstante a disponibilidade manifestada pelos referidos docentes, para se reconverterem às exigências e objectivos da nova Faculdade de Letras, a média das respectivas idades (54 anos), assim como a experiência anterior, de ensino e investigação, na Faculdade de Teologia, condicionaram o seu desempenho na nova Faculdade.

Por outro lado, também o tempo que estiveram ao serviço da FLUC e o respectivo empenho e dedicação foram diferenciados. Deste modo, no que concerne a Francisco Martins e a Porfírio A. da Silva, ainda que por motivos diferentes, o seu contributo foi modesto. Francisco Martins - de quem se pode afirmar, em sentido literal, que faleceu no seu posto, isto é, em plena aula, no dia 16 de Maio de 1916 -, somente exerceu funções docentes durante cinco anos (1911-1912 a 1915-1916), tendo leccionado as cadeiras de História Geral da Civilização e História Medieval. Por seu turno, Porfírio António da Silva - que regeu, esporadicamente, História Antiga e História Moderna I - dispersou-se por diversas outras actividades (políticas, empresariais e relacionadas

${ }^{32}$ Actas de Teologia, vol. 6 (1901-12), fl. 55-59, apud Manuel Augusto Rodrigues, «Da Faculdade de Teologia para a Faculdade de Letras da Universidade de Coimbra», Revista de História das Ideias, 11: Cultura, Política e Mentalidades, 1989, p. 537. 
com a instrução), além de também ter sido afectado pela doença, vindo a falecer em 24 de Fevereiro de $1919^{33}$.

Bem mais significativo foi o papel dos outros dois docentes, oriundos da Faculdade de Teologia: António Garcia Ribeiro de Vasconcelos e António Joaquim Alves dos Santos, com destaque para o primeiro. Na veradade, António Ribeiro de Vasconcelos (1860-1941) foi o grande impulsionador da FLUC, nas suas primeiras décadas, tendo-se destacado não só como docente e investigador de elevado mérito - a quem se ficaram a dever para cima de duas centenas de títulos -, mas também como gestor, administrador, organizador e ainda do ponto de vista político, tendo militado no Partido Progressista até à proclamação da República. Regeu diversas cadeiras: História Antiga, História de Portugal e várias das então chamadas ciências auxiliares da Históriaa ${ }^{34}$ (Paleografia, Diplomática, Epigrafia, Numismática e Esfragística).

Relativamente ao seu papel, neste âmbito, é elucidativo o testemunho de Damião Peres (1933) - a propósito de uma homenagem que iria ser prestada ao seu colega por antigos discípulos, à qual a FLUC se associou -, colocando "particularmente em evidência o que lhe devem, entre nós, as ciências auxiliares da história, as quais [...], antes do impulso que lhes deu o Dr. Vasconcelos, quase que não existiam em Portugal. Testemunho vivo e eloquente do que foi o esforço do Dr. Vasconcelos são as salas de Paleografia e Esfragística desta Faculdade, obra exclusivamente sua. A colecção de selos e de matrizes da sala de Esfragística é, sem contestação [...], a melhor do país. Nestes termos, propõe que, como um dos números do programa de homenagem, venha a ser dada a uma daquelas salas o nome do Dr. Vasconcelos» (proposta aprovada, por unanimidade, pelo Conselho da FLUC) ${ }^{35}$.

${ }^{33}$ VASCONCELOS, António de, «Dr. Porfírio da Silva», Revista da Universidade de Coimbra, vol. VIII, 1922, p. 613-614.

${ }^{34}$ Devido ao seu desenvolvimento e ao grau de autonomia entretanto adquirido pela referidas disciplinas, em vez de ciências auxiliares é preferível designá-las por "ciências colaboradoras" ou "ciências complementares" (DELORT, Robert, Introduction aux sciences auxiliaires de l'histoire, col. "U”, Paris, A Colin, 1969, p. 9-10)

${ }^{35}$ «Acta da sessão extraordinária de 29 de Março de 19233», M. A. Rodrigues, Actas da Faculdade de Letras, vol. II (1925-1933), p. 209-210. 
No âmbito da investigação, além do seu próprio exemplo, como investigador exímio e de grande produtividade, foi também ele o grande dinamizador do Instituto de Estudos Históricos, ao qual, em sua homenagem, lhe viria a ser dado o seu nome (1937-1974). Este instituto foi o primeiro a ser criado na FLUC, logo nos seus inícios, em 1911. Em 1932, era salientada a actividade desenvolvida por aquele - na iniciação de vários alunos nos métodos de investigação histórica e na elaboração, por parte dos professores, de valiosas monografias -, justificando-se, assim, a proposta para que fosse concedido o título de Instituto de Investigação Científica ao Instituto de Estudos Históricos, nos termos do art. ${ }^{\circ} 1 .^{\circ}$ do decreto n. ${ }^{\circ} 19026$ (acta de 12 de Dezembro de 1932) ${ }^{36}$. António Ribeiro de Vasconcelos veio a falecer em 1941, ano em que começava a vir a lume a Revista Portuguesa de História - iniciativa para a qual muito contribuiu e cujas raízes radicam no incremento dado à pesquisa histórica por aquele investigador -, a nossa mais antiga revista de história, em publicação ${ }^{37}$.

Em síntese, acerca do seu ex-colega, sublinhava Gonçalves Cerejeira (1940): «A sua erudição vasta, precisa e segura; o seu sereno equilíbrio de critério; a sua extraordinária faculdade de observação paciente, minuciosa e fiel; a sua arte pedagógica de dizer e ensinar; o seu grande poder de realização (de que o edifício e a organização da Faculdade de Letras são monumento perene); a sua intuição artística; a sua compreensão larga e benévola: - tudo isto a meus olhos o impunha como o Primeiro de todos os que a seu lado éramos mestres ${ }^{38}$.

No que se refere a Augusto Joaquim Alves dos Santos (1866-1924) - também, como Joaquim de Carvalho, integrado na Secção de Ciências Filosóficas - deu um contributo significativo na leccionação

${ }^{36}$ Idem, p. 196-200.

${ }^{37}$ Posteriormente, outras revistas viriam a ser criadas na área da História, entre as quais: Conimbriga (Instituto de Arqueologia); Revista de História das Ideias (Instituto de História e Teoria das Ideias), Estudos do Século XX (Centro de Estudos Interdisciplinar do Século XX - CEIS 20); Revista de História da Sociedade e da Cultura (Centro de História da Sociedade e da Cultura).

${ }^{38} \mathrm{M}$. Gonçalves Cerejeira, extra-texto manuscrito, Revista Portuguesa de História, t. I, 1940, p. 6-6, apud MENDES, José M. Amado, «A História na Faculdade de Letras da Universidade de Coimbra: Investigação e ensino (1911-1926)», Universidade(s). História. Memória. Perspectivas. Actas do Congresso "História da Universidade". (No 7. Centenário da sua Fundação). 5 a 9 de Março de 1990, vol. 1, Universidade de Coimbra, 1990, p. 490. 
de História Moderna e Contemporânea. Ao invés do que viria a constatar-se em décadas posteriores, em que a História Contemporânea foi sendo, quase sistematicamente, "esquecida", Alves dos Santos dava o devido destaque à Revolução Francesa e às problemáticas do século XIX. Por exemplo, no ano lectivo de 1915-1916, dedicou catorze aulas à Revolução Francesa (de 25 de Março a 20 de Maio de 1915), tendo inclusive focado a história da Inglaterra e da Alemanha até um período relativamente próximo. Ao facto não eram alheios os ideais republicanos que professava ${ }^{39}$.

Ainda durante a I República, novos professores reforçaram o quadro docente da FLUC, a maior parte dos quais viria a fazer a transição para o período seguinte, nomeadamente: Eugénio de Castro e Almeida (1869-1944) que regeu a cadeira de Arqueologia; Paulo Merêa (1889-1977), professor da Faculdade de Direito que leccionou, na FLUC, História de Portugal I; Vergílio Correia Pinto da Fonseca (1888-1944) que se encarregou da docência das cadeiras de História Antiga, História da Arte e Arqueologia; Joaquim de Carvalho (1892-1958), da Secção de Ciências Filosóficas mas que regeu História Geral da Civilização, de 1918 a 192240; e Manuel Gonçalves Cerejeira (1888-1977). Pelo número de cadeiras asseguradas e pelos aspectos inovadores da sua docência, analisemos mais de perto o papel deste último.

Manuel Gonçalves Cerejeira regeu um conjunto numeroso de cadeiras, a saber: História Geral da Civilização, História Antiga, História Medieval, História Moderna e Contemporânea, História de Portugal I, História das Religiões e Propodêutica Histórica. Como já tive o ensejo de afirmar noutro trabalho, por volta de 1925-1926, «do ponto de vista docente, era ele o grande suporte da Secção de História da Faculdade de Letras de Coimbra, pois regia seis das respectivas cadeiras. Com uma obra relativamente vasta (mais de meia centena de títulos), sobre diversas temáticas, devem-se-lhe importantes

\footnotetext{
${ }^{39}$ Idem, p. 489.

${ }^{40}$ Em 19 de Outubro de 1923, alegando manifesta falta de tempo, Joaquim de Carvalho reitera a sua escusa da regência da cadeira de História da Civilização (M. A. Rodrigues, Actas da Faculdade de Letras, vol. I (1911-1925), p. 221.
} 
trabalhos, por exemplo, sobre a Idade Média e o Renascimento. Eram, aliás, estas temáticas que mais privilegiava nas suas lições» ${ }^{41}$.

Pelos motivos acabados de explicitar, pode dizer-se que a História na FLUC, nas primeiras duas décadas (1911-c.1930), sem esquecer o contributo de outros docentes, muito ficou a dever à importante acção de A. Ribeiro de Vasconcelos, Gonçalves Cerejeira e Alves dos Santos. O primeiro pôs em prática os princípios fundamentais da história metódica, pela sua dedicação à preservação e ao estudo minucioso das fontes, ao desenvolvimento das ditas ciências auxiliares da história e às perspectivas com que focava a história de Portugal, dando relevo especial a eventos, sobretudo políticos e institucionais, e a personalidades ligadas às instituições políticas (com destaque para os reinados), militares e religiosas ${ }^{42}$. $\mathrm{O}$ ensino da história que praticava (história docência) tinha por alicerce um grande investimento no âmbito da investigação (história ciência), o que também foi meritório, numa altura em que se começava a profissionalizar a actividade de historiador. Por sua vez, Gonçalves Cerejeira não se limitava à descrição factual e cronológica, mas interessava-se, igualmente, pela interpretação e construção históricas, o que já o aproxima mais da história positivista. A sua formação e ambiente religioso em que se movia, como eclesiástico e futuro Cardeal Patriarca de Lisboa (1929-1971), levava-o, no entanto, a dar relevo particular a determinadas temáticas, entre as quais se encontrava uma certa "reabilitação" da Idade Média. Em vez de a considerar sob o ponto de vista mais negativo - são conhecidas expressões como "mil anos sem banhos" e "mil anos sem luz", aplicadas àquela época histórica -, perspectivava-a como um período de conquistas importantes, no contexto da civilização ocidental e cristã. Alves dos Santos, como se disse já, ao abordar períodos e eventos históricos recentes - numa espécie de antecipação

${ }^{41}$ José A. Mendes, «A História na Faculdade de Letras da Universidade de Coimbra ...»,p. 492.

${ }^{42} \mathrm{O}$ que acaba de referir-se pode ser confirmado, por exemplo, pela consulta dos sumários da cadeira de História de Portugal, dada por António Ribeiro de Vasconcelos, no ano lectivo de 1916-17, cujo programa contemplou o período dos finais do século XI até à expedição a Tânger. Estes e outros sumários de diversas cadeiras de História encontram-se no Arquivo da Universidade de Coimbra (AUC). Ao seu Director, colega e amigo Doutor José Pedro Paiva, manifesto a minha gratidão, pelas facilidades concedidas na sua consulta. 
da hoje chamada história do presente - se, por um lado, se mantinha fiel à tradição oitocentista, por outro destacava-se entre os colegas que se interessavam mais por realidades históricas remotas, com prejuízo das mais próximas, tendência que viria a prevalecer na FLUC, ao longo de mais de meio século.

\section{Da I República aos anos de 1960}

A História, associada à Geografia até 1929-1930 (licenciatura Ciências Históricas e Geográficas) ${ }^{43}$, a partir de então e até 1957 , passou a estar geminada com a Filosofia (licenciatura Ciências Históricas e Filosóficas) ${ }^{44}$. Em termos genéricos, a história atravessou então um período de três décadas pouco auspicioso. Segundo a opinião de Vitorino Magalhães Godinho, «a historiografia portuguesa, a partir do segundo quartel do século XX, vai-se perder, ou nas ideias feitas do passado, ou na análise minuciosa de pormenores muitas vezes sem relevância». Para ilustrar estes dois aspectos, V. M. Godinho recorre à análise da obra de João Lúcio de Azevedo e de Queiroz Veloso ${ }^{45}$.

No que toca à FLUC, o panorama não se apresenta muito diferente, embora não se deva generalizar. Do conjunto das vinte disciplinas que integravam a licenciatura em Ciências Históricas e Filosóficas (reforma de 1929-1930), onze eram da área de História ${ }^{46}$. Em linha com a tradição da FLUC, as ciências "auxiliares" continuavam a ter um grande peso, assim como a história antiga e medieval, enquanto a história moderna e contemporânea estavam concentradas numa só cadeira, do que resultava uma quase ausência da história contemporânea, nos conteúdos

${ }^{43}$ Decreto n. ${ }^{\circ} 17$ 063, de 3 de Julho de 1929 e Decreto n. ${ }^{\circ} 18003$, de 25 de Fevereiro de 1930 .

${ }^{44}$ Decreto n. ${ }^{\circ} 41341$, de 30 de Outubro de 1957.

${ }^{45}$ GODINHO, Vitorino Magalhães, «A historiografia portuguesa ao longo do século XX - Orientações, problemas, perspectivas», Ensaios, III: Sobre Teoria da História e Historiografia, Lisboa, Livraria Sá da Costa Editora, 1971, p. 232.

${ }^{46}$ História da Antiguidade, História Oriental, História da Antiguidade Clássica, Epigrafia, História Medieval, História de Portugal, Numismática e Esfragística, História Moderna e Contemporânea, Arqueologia, Paleografia e Diplomática, Estética e História da Arte (NUNES, João Paul Avelãs, A História Económica e Social na Faculdade de Letras da Universidade de Coimbra. 1911-1974, Lisboa, Instituto de Inovação Educacional/Ministério da Educação, 1995, p. 77). 
programáticos da disciplina. Por outro lado, o corpo docente era exíguo para assegurar aquele número de cadeiras, como foi igualmente limitado o número de docentes (apenas cinco) que, nesse período, se doutorou em história: Mário Brandão (1933), Torquato de Sousa Soares (1935), Manuel Lopes de Almeida (1940), Avelino Jesus da Costa (1959) e Salvador Dias Arnaud (1960).

Além das disciplinas de carácter mais metodológico - nas quais se tinha obtido um grau de aperfeiçoamento considerável -, noutros casos seguia-se uma perspectiva essencialmente factual e cronológica, destacando-se os feitos dos homens considerados excepcionais ${ }^{47}$. Tratava-se, em certa medida, de ajudar a criar "uma mentalidade colonial" - ou de império ultramarino, a partir de 1953 -, como expressamente se referia na proposta de criação de um Instituto de Estudos Coloniais, apresentada em reunião do Senado (26-7-1945) ${ }^{48}$.

Acrescente-se, no entanto, que em certos aspectos se deram passos importantes, em temos de inovação. Assim, de 1946 a 1951, por iniciativa de Torquato de Sousa Soares, foram organizados na FLUC cursos especializados em história económica e social, com a colaboração de professores estrangeiros convidados: Charles Verlinden e Yves Renouard ${ }^{49}$. Ainda que de forma esporádica e sem consequências imediatas no conjunto do ensino-aprendizagem da história na FLUC e apesar da influência da escola dos Annales $^{50}$ só mais tarde se ter feito sentir de forma mais nítida, aquelas iniciativas revelam que "novos ventos" começavam a chegar à história praticada na Faculdade.

Alguns dos docentes de história também participaram em obras colectivas de grande fôlego, nas quais puderam dar conta das investigações efectuadas. Entre outras, refira-se a História de Portugal

${ }^{47}$ Por exemplo, na cadeira de História dos Descobrimentos, leccionada por Salvador Dias Arnaud, no ano lectivo de 1956-1957, foi dado grande relevo às viagens de exploração marítima e aos seus protagonistas (AUC, Sumários de História dos Descobrimentos, 1956-1957).

${ }^{48}$ AUC, "Senado. Actas", livro 6, fl. 21.-21v.

${ }^{49}$ J. P. Avelãs Nunes, op. cit., p. 59-61).

${ }^{50}$ Da revista Annales d'Histoire Économique et Sociale (veículo privilegiado da nova história, cujo nome veio a sofrer posteriormente ligeiras alterações) apenas chegaram à FLUC alguns números no início dos anos de 1930, vindo a ser assinada pelo Instituto de Estudos Históricos apenas a partir dos anos de 1960. 
(1928-1958) $)^{51}$, dirigida por Damião Peres, professor da FLUC ${ }^{52}$. Além do próprio Damião Peres, coordenador e colaborador, participaram ainda na referida obra os docentes da FLUC Vergílio Correia, Joaquim de Carvalho e Manuel Lopes de Almeida. Trata-se de uma obra de referência, só em parte superada nas últimas décadas por iniciativas análogas, não obstante a sua utilidade ser prejudicada pela escassez de referências bibliográficas e arquivísticas. Também os professores da FLUC Damião Peres, Joaquim de Carvalho e Torquato de Sousa Soares colaboraram noutra obra colectiva, História da Expansão Portuguesa no Mundo (3 vols., 1937-1940) (33 $^{5}$ além de terem igualmente participado em diversos eventos científicos.

A evolução da história na FLUC, nas décadas de 1930-1950, a acrescentar à já referida exiguidade do corpo docente e à dispersão de alguns dos seus elementos por actividades políticas extra-universitárias, foi ainda prejudicada por outros factores, decorrentes da política e da ideologia em vigor, durante a Ditadura Militar (1926-1932) e o Estado Novo (a partir de 1933). As directivas legais para o ensino da história, estabelecidas logo em 1932, ainda que destinadas ao ensino secundário e técnico profissional, não deixaram de se reflectir na própria Universidade. Com efeito, segundo o Decreto n. ${ }^{\circ} 21104$, de 7 de Abril de 1932: «Deve ser objecto de justificação e glorificação tudo quanto se tem feito, através dos oito séculos de Portugal, no sentido de fortalecer os seguinte factores fundamentais da vida social: a Família, como célula social; a $F e ́$, como estímulo da expansão portuguesa por mares e continentes e elemento da unidade e solidariedade nacional; o Princípio da autoridade, como elemento indispensável do progresso geral; a Firmeza do Governo, espinha dorsal da vida política do País; o Respeito da hierarquia, condição básica da cooperação dos valores; e a Cultura Literária e Científica» Ao invés, «tudo quanto [...] tem sido elemento de dissolução nacional, de enfraquecimento da confiança no

${ }^{51}$ A obra consta de 7 volumes, 1 volume de índices e 1 suplemento (1928-1958), ao qual foi acrescentado um II suplemento, da autoria de Franco Nogueira, em 1981 .

${ }^{52}$ Anteriormente (1919-1928), Damião Peres (1889-1976) foi professor da Faculdade de Letras da Universidade do Porto, após o que passou a integrar o quadro de docents da Faculdade de Letras da Universidade de Coimbra (1931-1959).

${ }^{53}$ Dirigida por Hernâni Cidade e Manuel Múrias. 
futuro, falta de gratidão para com os esforços dos antepassados, deve ser objecto de censura» ${ }^{54}$.

Factor não menos relevante terá sido o dos critérios usados no recrutamento do pessoal docente, veementemente denunciado relativamente à Universidade, como um todo - por Aurélio Pereira da Silva Quintanilha (1892-1987), em 1933, nos seguintes termos: «A Universidade não produz porque o recrutamento dos elementos novos é feito pelos velhos, que seleccionam à sua imagem e semelhança, pessoas com a mesma mentalidade e que não sejam elementos perturbadores ${ }^{55}$. Como exemplo concreto dos métodos de recrutamento e dos critérios políticos e ideológicos - que, por vezes, se sobrepunham aos científicos e pedagógicos -, pode apontar-se o caso de António Sérgio. Tendo sido proposto pelo Conselho da Faculdade - apoiado, entre outros, por Joaquim de Carvalho, mas com voto contra de Damião Peres - para a regência da Cadeira de Pedagogia e Didáctica (Secção de Ciências Pedagógicas), não obstante o parecer favorável do dito Conselho, decisão ministerial recusou a sua nomeação, alegando: «no momento actual, devia considerar-se como inviável a nomeação do Sr. António Sérgio para a regência da referida cadeira ${ }^{56}$.

\section{Inovação vs. Tradição (c. 1960-1974)}

Desde a reforma da FLUC de 1957, a licenciatura em História autonomizou-se da de Filosofia, pelo que a respectiva Secção passou a ter que assegurar serviço docente acrescido. De facto, em vez das onze disciplinas de história que assegurava na licenciatura em Ciências Históricas e Filosóficas (1930-1957), a partir de então competia-lhe

${ }^{54}$ Acerca do conteúdo do decreto citado, ver também TORGAL, Luís Reis, História e ideologia, Coimbra, Minerva, 1989, p. 32-33.

55 AUC, "Senado. Actas", vol. 4, fls. 122v.-124. Na sequência das suas intervenções, o docente e investigador viria a ser expulso da Faculdade de Ciências da Universidade de Coimbra, em 1935 (Decreto-Lei n. ${ }^{\circ}$ 25317, de 13 de Maio de 1935).

${ }^{56}$ TORGAL, Reis, MENDES, José Amado e CATROGA, Fernando, História da História em Portugal. Séculos XIX e XX, 2 vols., Lisboa, Temas \& Debates, 1998, p. 279-280. 
leccionar vinte e três ${ }^{57}$, das vinte e quatro obrigatórias, de um total de vinte e sete. Algumas áreas foram reforçadas, com a criação de novas cadeiras, entre as quais as de Teoria da História, Pré-História e História do Cristianismo. Por sua vez, foi definitivamente extinta a cadeira generalista de História Geral da Civilização, mas reforçou-se o domínio da Cultura, com a criação de quatro novas cadeiras, contemplando as épocas clássica, medieval e moderna (mas não a contemporânea) e a realidade portuguesa. A criação destas disciplinas visou atenuar os efeitos da separação entre a história e a filosofia (em termos de licenciatura, pela reforma de 1957), com a seguinte justificação: «não pareceu aconselhável a inteira separação, não só por se oporem a isso as finalidades práticas das licenciaturas, mas também por ser tão precisa ao historiador a formação filosófica como o saber histórico ao especialista de filosofia. A criação de cadeiras de História da Cultura, de âmbito simultaneamente filosófico e historiográfico, que figuram no novo elenco da nova licenciatura em História e da nova licenciatura em Filosofia, permitiu uma solução que se reputa equilibrada ${ }^{58}$.

Se algumas das novas disciplinas se integravam em áreas já com tradição na FLUC, outras houve para as quais foi necessário recrutar novos docentes, regra geral assistentes. Apesar de não se ter realizado nenhum doutoramento em História, na FLUC, nos anos de 1960, simultaneamente com a leccionação das diversas disciplinas, os docentes, entretanto contratados, foram efectuando investigação, grande parte da qual com vista à elaboração das teses de doutoramento. Os resultados surgiram nos primeiros anos da década seguinte, com a realização de quatro doutoramentos em História: António de Oliveira (1971), Luís Ferrand de Almeida (1973), Jorge Alarcão e Manuel Augusto Rodrigues

${ }^{57} \mathrm{O}$ elenco das referidas disciplinas (algumas das quais semestrais) era o seguinte: Teoria da História, Pré-História, História da Antiguidade Oriental, História da Civilização Grega, Paleografia e Diplomática, História da Civilização Romana, História da Cultura Clássica, Arqueologia, História da Arte, Epigrafia, Numismática, História da Idade Média, História da Cultura Medieval, História de Portugal I, História da Arte Portuguesa e Ultramarina, História Moderna e Contemporânea, História da Cultura Moderna, História de Portugal II, História da Expansão Portuguesa, História do Brasil, História da Cultura Portuguesa, História do Cristianismo e Seminário (opcional) (Decreto n. ${ }^{\circ} 41341$, de 30 de Outubro de 1957).

${ }^{58}$ Decreto n. ${ }^{\circ} 41$ 341, de 30 de Outubro de 1957. 
$(1974)^{59}$. Independentemente das motivações e dos interesses de cada um, a regência das cadeiras que tiveram a seu cargo - a exemplo do que tem sucedido com vários outros docentes - terá pesado na escolha da temática das respectivas teses de doutoramento, como se comprova, relacionando as disciplinas que cada um leccionou com as temáticas investigadas. Ao associar as duas vertentes, contribuíram para eliminar aquilo que V. Magalhães Godinho classificou como o "cruciante drama do ensino em Portugal", que era o seu divórcio da investigação ${ }^{60}$.

De finais dos anos cinquenta aos inícios dos anos setenta, a área da história económica e social começou a ser mais valorizada e, com ela, passaram então a fazer-se sentir, com maior evidência, os reflexos da nova história que começou a estar presente no ensino e na investigação efectuada. Revelam-no, além dos temas das respectivas teses e de outros trabalhos publicados, os conteúdos focados por vários dos seus docentes, nas disciplinas de História. Como exemplos, entre outros, recordem-se as cadeiras de História de Portugal I (Luís Ferrand de Almeida, 1959-1960), História da Civilização Romana (Jorge Alarcão, 1968-1969) e História Moderna e Contemporânea de Portugal (António de Oliveira, 1972-1973) ${ }^{61}$. Apesar de, entretanto, já terem decorrido três décadas, constata-se que a abertura a novas temáticas e áreas da história se distinguia consideravelmente do que se verificava nos anos de 1930, quando o Instituto de Estudos Históricos apenas integrava as secções de Estudos Medievais, História Ultramarina de Portugal e Numismática ${ }^{62}$.

No âmbito da História da Cultura, destacou-se a acção relevante desempenhada por José Sebastião da Silva Dias, através das cadeiras de cultura que leccionou e do Seminário de Cultura Portuguesa que orientou a partir de finais dos anos de 1950, no âmbito do qual foram elaborados trabalhos, vários dos quais publicados - sobre a época contemporânea, com destaque para o século $\mathrm{XIX}^{63}$. Tratou-se de um impulso importante dado ao estudo da história mais recente -

${ }^{59}$ J. P. Avelãs Nunes, op. cit., p. 188.

${ }^{60}$ V. Magalhães Godinho, op. ci., p. 244.

${ }^{61}$ AUC, "Livros de sumários" das cadeiras mencionadas.

62 “Acta da sessão ordinária de 6 de Fevereiro de 1936”, M. A. Rodrigues, Actas da Faculdade de Letras, II, p. 334.

${ }^{63}$ Com o magistério de J. S. da Silva Dias se iniciaram na investigação, entre muitos outros, Luís Reis Torgal, Amadeu de Carvalho Homem, Fernando Almeida Catroga, Maria Manuela Tavares Ribeira e Zília Osório de Castro. 
tradicionalmente afastada da FLUC, com a excepção já referida de Alves dos Santos, na I República -, para o que também muito contribuiu João Lourenço Roque, ao dar especial relevo ao século XVIII e à própria Revolução Francesa de1789, na cadeira de História Moderna e Contemporânea (desde o ano lectivo de 1970-1971). Acrescente-se, ainda, que foi também neste período (c. de 1960-1974) que a se aprofundou o grau de especialização da história, no âmbito de outros institutos entretanto criados: Instituto de História Ultramarina, Instituto de Arqueologia, Instituto de História da Arte ${ }^{64}$.

Pela reforma de 1968 foi criado o bacharelato - obtido, uma vez completado o primeiro ciclo de estudos de três anos, após o que, com mais dois anos, seria obtida a licenciatura -, para dar resposta premente necessidade de pessoal docente, «em virtude da extraordinária afluência ao ensino secundário ${ }^{65}$. Aquele era obtido através da realização de dezasseis cadeiras, cobrindo as diversas épocas da evolução histórica, sendo outras, do âmbito mais teórico - como a Teoria da História - ou das "ciências auxiliares" (Paleografia e Diplomática, Epigrafia, Numismática e Arqueologia) sido remetidas para os dois anos seguintes, de licenciatura.

\section{O pós-25 de Abril de 1974: transformações revolucionárias e respectivos ajustes}

Na sequência da revolução Abril de 1974, operam-se transformações profundas na sociedade portuguesa e, obviamente, também no ensino-aprendizagem da história e no respectivo enquadramento, legislativo e institucional. $\mathrm{Na}$ impossibilidade de, nas presentes circunstâncias, desenvolver o assunto com a profundidade e amplitude que ele merece,

${ }^{64}$ Recorde-se o papel então desempenado por António Nogueira Gonçalves, em cujos sumários fazia frequentemente esboços de desenhos, para tornar a compreensão da matéria mais acessível aos alunos voluntários, que não tinham podido assistir às suas aulas (Ex.: AUC, "Sumários de História da Arte", 1971-1872, de António Nogueira Gonçalves). Com Nogueira Gonçalves se começou a constituir um grupo de docentes dedicados à história da arte, como Pedro Dias, Maria Regina Anacleto e Nelson Correia Borges, entre outros.

${ }^{65}$ Decreto n. ${ }^{\circ} 48$ 627, de 12 de Outubro de 1968. 
limitar-me-ei a focar, ainda que de modo sucinto, alguns dos aspectos que considero mais relevantes.

As profundas alterações introduzidas decorreram, por um lado, das respectivas conjunturas políticas e ideológicas e das suas rápidas alterações e, por outro, da necessidade de dar resposta às novas exigências da comunidade, em termos não só científicos e pedagógicos como também de empregabilidade e mercado do trabalho. Assim, os planos de estudo e de investigação foram sendo profundamente alterados, de harmonia com as circunstâncias.

No imediato pós-25 de Abril de 1974, mais por movimento espontâneo de docentes e alunos do que por determinação governamental ou legislativa, os planos da licenciatura em história e os conteúdos das disciplinas foram profundamente alterados. A propósito, já foi salientado, relativamente ao todo nacional: «Importantíssima foi sem dúvida a verdadeira febre historiadora que aqueceu as mentes jovens pelo menos até 1976, quando tudo parecia possível e era preciso realizar-se, abrir-se ao mundo, absorver em poucas semanas tudo o que o fascismo mantivera por anos à margem da vida estudantil e académica. O surgimento de novas universidades, as mudanças havidas nas mais antigas, a abertura generalizada ao estudo e ensino das ciências sociais, eis outros tantos factos cuja importância seria inútil negar quando se quer avaliar os rumos historiográficos desse período» ${ }^{66}$.

Numa altura em que praticamente tudo era posto em causa, com vista a enveredar-se por caminhos novos - finais de 1974 e inícios de 1975 -, a reestruturação dos cursos de bacharelato e de licenciatura em História da FLUC foi aprovada em Plenário, realizado no dia 11 de Outubro de 1974 e começou a funcionar, experimentalmente, em Fevereiro de 1975. Entre outros aspectos inovadores daquela reforma destacam-se: a) a manutenção do bacharelato, «por não existirem escolas especialmente destinadas à formação de professores do ensino secundário», a completar por uma formação psico-pedagógica; b) grande flexibilidade na organização do elenco de cadeiras a frequentar pelos alunos, através do estabelecimento de um número reduzido de disciplinas obrigatórias e de um vasto leque de opcionais; c) a definição

\footnotetext{
${ }^{66}$ FALCON, Francisco, «Historiografia Portuguesa Contemporânea. Um ensaio historiográfico-interpretativo», Estudos Históricos [Rio de Janeiro], n. . 1, 1988, p. 94.
} 
da licenciatura como pré-especialização, contemplando-se várias possibilidades, de acordo com o interesse do aluno; d) a secundarização da História de Portugal - no elenco das disciplinas obrigatórias - e a criação de cadeiras de carácter geral e universal, através das quais se estudariam problemáticas até então ausentes dos respectivos programas.

A estrutura básica dos cursos (bacharelato e licenciatura) assentava em três cadeiras propedêuticas, seis obrigatórias e de, pelo menos, duas disciplinas opcionais. Embora os ideais da história nova - já introduzidos em anos anteriores - continuassem presentes e a serem incrementados no ensino-aprendizagem da história, nesta fase predominaram as influências do materialismo histórico e do marxismo, como se pode inferir das próprias designações das cadeiras, consideradas nucleares ${ }^{67}$. Do elenco das disciplinas opcionais aquelas que, até então, eram consideradas básicas ou foram abolidas ou reformuladas (por exemplo, em vez de História de Portugal surge Formação de Portugal), enquanto outras mantiveram designação análoga (História da Expansão de Portugal), surgindo ainda várias disciplinas novas como: História do Renascimento e do Barroco em Portugal, História do Absolutismo e do Iluminismo em Portugal, História do Liberalismo em Portugal, História da República em Portugal, História Comparada das Religiões, História dos Movimentos Ideológicos, História das Ideias Políticas, Ideológicas e Religiosas (várias cadeiras) ${ }^{68}$.

Em 1978, passados os ventos revolucionários mais intensos, nova reforma se verifica - aplicada às Faculdades de Letras -, tendo-se então começado a fazer os necessários ajustes. De facto, alivia-se a carga ideológica que constava das designações - e, obviamente, dos conteúdos - das disciplinas, atribuindo-se-lhes nomes neutros ou, pelo menos, menos marcados ideologicamente. Por exemplo, em vez de Sociedades Esclavagistas, passam a existir as cadeiras de Sociedades,

${ }^{67}$ Ano propedêutico: Introdução aos Estudos Históricos; Introdução à História Económica e Social e Introdução à Epistemologia das Ciências Humanas $e$ Sociais. As seis cadeiras obrigatórias, que se seguiam às do ano propedêutico, eram: Origens do Homem e da Civilização; História das Sociedades Esclavagistas, História das Sociedades Feudais, História do Pré-Capitalismo e do Capitalismo Comercial; História do Capitalismo Industrial e da Génese do Socialismo e História do Capitalismo Monopolista e do Socialismo.

${ }^{68}$ Departamento de História. Reestruturação de cursos e organização do Departamento. Faculdade de Letras, 1974-1975; idem, 1975 (pol. ${ }^{\circ}$ ). 
Culturas e Civilizações Pré-Clássicas e Sociedades, Culturas e Civilizações Clássicas. A problematização - um dos emblemas da nova história - é valorizada, com a criação, além da reintrodução da História de Portugal, da disciplina de Problemática da História de Portugal. Também as questões tóricas e metodológicas adquiriram relevância, com a criação das seguintes cadeiras: Matemática para as Ciências Humanas e Socais, Teoria das Fontes e Problemática do Saber Histórico e Teoria da História e do Conhecimento Histórico. Outras disciplinas (História da Arte, História Comparada das Religiões, Arqueologia, Paleografia e Diplomática, Epigrafia e Numismática, entre outras) voltaram a integrar o elenco das cadeiras obrigatórias. Por outro lado, constituiu medida do maior significado a substituição da óptica um tanto reducionista, de quase exclusividade, atribuída aos factores económicos e sociais, por outra em que o ensino da história, além da vertente económica e social, passasse a integrar igualmente as perspectivas institucional e política, cultural e das mentalidades e artística ${ }^{69}$. Também se começava então a ter consciência de que as Faculdade de Letras não deveriam limitar-se a formar professores - ponto de vista que se mantém actualizado mas que ainda não foi devidamente interiorizada pela comunidade -, pois os seus licenciados estavam igualmente habilitados a desempenhar outras actividades laborais, «como as de se exercerem em bibliotecas, arquivos e museus, gabinetes de urbanismo e planeamento regional e local, administração pública e privada, relações públicas, relações internacionais, intervenção social e cultural, etc.» ${ }^{70}$.

Pouco mais de uma década depois (1986 e 1987), novas reformas se concretizaram. Pela de 1986, foram criados três tipos de licenciatura em História (História e Variantes em Arqueologia e em História da Arte), ao mesmo tempo que se atribuiu maior destaque à história contemporânea, com a introdução de disciplinas específicas sobre esse período: História da Época Contemporânea e História Contemporânea de Portugal $^{71}$. Por sua vez, pela reforma de 1987, a FLUC vai passar a ter uma intervenção mais activa na formação para a docência (do ensino básico e secundário), além da parte que já lhe cabia, no que concerne aos conteúdos científicos, desde a sua fundação. Assim, após um

\footnotetext{
${ }^{69}$ Decreto n. ${ }^{\circ}$ 53/78, de 31 de Maio de 1978, art. ${ }^{\circ}$ 7, 4.

${ }^{70}$ Ibidem

${ }^{71}$ Portaria n. ${ }^{\circ}$ 508/86, de 10 de Setembro de 1986.
} 
período de estudo inicial de três anos, os alunos poderiam optar por um conjunto de disciplinas optativas em ciências da educação que, uma vez concluídas, lhes davam acesso a um $5 .^{\circ}$ e último ano (com a realização de um seminário na FLUC e de um estágio pedagógico, num escola do ensino básico e secundário), findo o qual se obtinha a licenciatura em História - Ramo Educacional ${ }^{72}$.

A remodelação dos cursos de História, a criação dos Mestrados, a partir de finais dos anos de 1980 e a criação de novas disciplinas - simultaneamente com uma procura elevada por parte dos alunos, inclusive estudantes trabalhadores, como voluntários, no pós-25 de Abril -, de 1974 até à década de 1990, levou ao recrutamento de um número considerável de docentes, geralmente como assistentes que, entretanto, foram preparando os seus doutoramentos. Foi também nesse período que a Secção de História finalmente se abriu ao recrutamento de docentes do sexo feminino, o que não sucedeu até $1974^{73}$. A diversidade de matérias leccionadas e a abertura dos docentes mais antigos, como orientadores, possibilitou o desenvolvimento da investigação em novas áreas, muitas delas de ponta, mesmo tendo em vista o contexto internacional ${ }^{74}$. Passou a haver também uma nova abertura a outras historiografias - inglesa, italiana, norte-americana e brasileira -, com a perda da hegemonia relativa da francesa, até 1974. A estrutura institucional, nomeadamente através da organização em institutos e em centros de investigação especializados - com certa autonomia científica e pedagógica - também contribuiu para o incremento da investigação, como apoio às disciplinas leccionadas pelos respectivos docentes ${ }^{75}$.

${ }^{72}$ Portaria n. ${ }^{\circ} 844 / 87$, de 26 de Outubro de 1987.

${ }^{73}$ Até essa altura, apenas Maria Helena da Cruz Coelho e Maria Àquila haviam sido contratadas como assistentes (ano lectivo de 1971-1972).

${ }^{74}$ Entre muitos exemplos, recordam-se: história económica e social de determinadas localidades ou áreas, demografia histórica, história agrária, história industrial e da mineração, história das comunicações, história das mulheres, história das instituições e das empresas, arqueologia industrial e museologia, turismo e património, biografia e prosopografia, história militar e história da ciência e tecnologia, história das mentalidades e das ideologias, história do republicanismo e do Estado Novo, sistemas políticos, movimentos culturais e artísticos, relações internacionais, etc.

${ }^{75}$ Praticamente tem-se mantido, sem alterações significativas, a organização, já estabelecida em 1975, em que existiam os seguintes Institutos: História Económica e Social (herdeiro do ex-Instituto Histórico Dr. António Ribeiro de 
Nos inícios da presente centúria, o Grupo de História da FLUC contava com mais de quarenta docentes doutorados (cujos nomes me escuso de mencionar, devido ao seu elevado número), constituindo o grupo mais numeroso do País com essa habilitação ${ }^{76}$. As suas teses de Doutoramento, parte delas publicadas, os seus trabalhos de investigação e a participação em números eventos, em Portugal e no estrangeiro - em alguns casos, certos docentes têm revelado um bom nível de internacionalização -, evidenciam o seu dinamismo e mostram como o Grupo de História (actualmente Departamento de História, Arqueologia e Artes) e os seus docentes se encontram em sintonia com os rumos que a História e a Historiografia têm vindo a seguir, ao longo do último século. Com efeito, embora, por vezes, com algum desfasamento temporal, também na história ensinada e investigada na FLUC se fizeram sentir as repercussões de escolas históricas e tendências, com destaque para a história metódica e positivista, a história nova, o materialismo histórico e, ainda que em menor grau, a história do presente. Aparentemente, só história virtual e o uso do contrafactual ainda não encontraram adeptos na FLUC.

Vasconcelos), História e Teoria das Ideias, História da Expansão e do Colonialismo (actual Instituto da Expansão Ultramarina), História da Arte, Paleografia e Diplomática e Arqueologia. Quanto aos centros de Investigação, entre outros, têm-se revelado bastante activos os de História da Sociedade e da Cultua, o Centro de Estudos Interdisciplinares do Século XX - CEIS XX e o Centro de Arqueologia. A exemplo do já referido para o Instituto de História da Arte (dinamizado por Nogueira Gonçalves e seus discípulos), devem destacar-se, igualmente, a dinamização e o impulso dados pelos seguintes docentes e colegas às seguintes áreas: História Económica e Social (Salvador Dias Arnaud, António de Oliveira, Luís Ferrand de Almeida e Maria Helena da Cruz Coelho); História e Teoria das Ideias (J. S Silva Dias, L. e Reis Torgal, Amadeu Carvalho Homem e Fernando Catroga): Paleografia e Diplomática (Avelino Jesus da Costa, Maria Helena Coelho, Maria José Azevedo Santos e Saul Gomes); Arqueologia (Jorge Alarcão, José d'Encarnação e Vasco Mantas); e História da Expansão Ultramarina (Salvador Dias Arnaud, João Marinho dos Santos e José Manuel Azevedo Silva).

${ }^{76}$ Recorda-se que já em 1993, vinte e um dos docentes do Grupo de História deram uma colaboração relevante à História de Portugal (dir. de José Mattoso, 8 vols. Lisboa, Círculo de Leitores, 1992-1994), ao elaborarem, sob a coordenação de Luís Reis Torgal e João Lurenço Roque, o volume V da dita obra; isto sem esquecer, obviamente, a participação em numerosas iniciativas, internas e externas, em que docentes de história da FLUC colaboraram. 
Antes de concluir, parece-me de inteira justiça sublinhar, reconhecer e manifestar a nossa gratidão a todos aqueles que, no seu tempo e nas condições de que dispunham - em certos casos bem adversas -, tudo fizeram para prestigiar e dignificar a história e o seu ensino-aprendizagem, a investigação histórica e a historiografia, de cuja dedicação e empenho todos nós pudemos beneficiar. Como elos dessa cadeia, também temos a nossa quota parte no processo, mas, no longo prazo, devemos reconhecer que, para chegarmos onde estamos, foi necessário o contributo de várias gerações - ao longo de uma centúria -, cuja acção nos compete prosseguir e superar, mas sem esquecer, igualmente, o muito que lhes devemos e o legado que nos transmitiram. Deste ponto de vista, parafraseando o monge de Chartres, nós somos como que anões, mas gozando de uma enorme prerrogativa, que é a de estarmos às costas de gigantes!

\section{Referências}

AROSTÉGUI, Julio, La historia vivida. Sobre la historia del presente, Madrid, Alianza Editorial, 2004.

Bibliografia Anual da História de Portugal da Pré-História a 1974, Coimbra, Faculdade de Letras da Universidade de Coimbra, 1989$-1995$.

BORDEAU, Louis, Histoire et historiens. Essai criqitique sur l'histoire coniderée comme science positive, Paris, Félix Alcan, 1888.

BOURDÉ, Guy e MARTIN, Ervé, Les écoles historiques, Paris, Ed. do Seuil, The Free Press, 1983.

BURGUIÈRE, André, «Histoire et structures». «Introduction», Annales. E. S. C., n. . 3-4, 1973.

CAINE, Barbara, Biography and history, Houndmills-Basingstoke, 2010.

CATROGA, Fernando, Caminhos do fim da História, Coimbra, Quarteto, 2003.

COELHO, Maria Helena et al. (Comissão Científica Supervisora), Repertório Bibliográfico da Historiografia Portuguesa. 1974-1994, Coimbra, Faculdade de Letras de Coimbra/Instituto Camões, 1996. DELORT, Robert, Introduction aux sciences auxiliaires de l'histoire, col. "U”, Paris, A Colin, 1969. 
FALCON, Francisco, «Historiografia Portuguesa Contemporânea. Um ensaio historiográfico-interpretativo», Estudos Históricos [Rio de Janeiro], n. ${ }^{\circ}$ 1, 1988, p. 79-99.

FERGUSON, Niall (coord.), História Virtual (trad. do inglês), Lisboa, Tinta da China, 2006.

FORSTER, Robert, «Achivementes of the Annales School», The Journal of Economic History, vol. XXXVIII, n. . 1, 1978, p. 58-76.

FUKUYAMA, Francis, O Fim da História e o último Homem (trad. do inglês), Lisboa, Gradiva, 1992.

GODINHO, Vitorino Magalhães, «A historiografia portuguesa ao longo do século XX - Orientações, problemas, perspectivas», Ensaios, III: Sobre Teoria da História e Historiografia, Lisboa, Livraria Sá da Costa Editora, 1971, p. 227-247.

HIMMELFARB, Gertrud, The new history and the old, Cambridge, Mass., Bleknap Press of Harvard University Press, 1987.

HUNTINGTON, Samuel P., The Clash of Civilizations and the Remaking of World Order, Nova Iorque, Simon \& Schuster, 1996.

KUHN, Thomas S., La structure des revolutions scientifiques (trad. do inglês), Paris, Flammarion, 1972.

LANGLOIS, Charles-Victor e SEIGNOBOS, Charles, Introdution aux «études historiques, Paris, Achete, 1898.

LÀZARO, Josep Fontana i, «Ascensão e decadência da Escola dos “Annales"», Histórias \& Ideias, vol. I, n. ${ }^{\circ} 3-4,1979$, p. 65-79.

Legislação - Decretos: 19 de Abril de 1911; 9 de Maio de 1911; n. ${ }^{\circ} 17$ 063, de 3 de Julho de 1929; n. ${ }^{\circ}$ 18003, de 25 de Fevereiro de 1930; n. ${ }^{\circ} 21104$, de 7 de Abril de 1932; n. 41 341, de 30 de Outubro de 1957; n. ${ }^{\circ} 48$ 627, de 12 de Outubro de 1968; n. ${ }^{\circ}$ 53/78, de 31 de Maio de 1978, art. $^{\circ}$ 7, 4. Portaria n. ${ }^{\circ}$ 508/86, de 10 de Setembro de 1986; Portaria n. $.^{\circ} 844 / 87$, de 26 de Outubro de 1987.

LYOTARD, Jean-François, A condição pós-moderna (trad. do francês), Lisboa, Gradiva 1989.

MARROU, H.-I, Do conhecimento histórico (trad. do francês), 2. ed., Lisboa, Ed. Aster, s/d.

MATTOSO, José (dir.), História de Portugal, vol. V: O Liberalismo (1807-1890), coord. de Luís Reis Torgal e João Lourenço Roque, Lisboa, Círculo de Leitores, 1993.

MAYER, Arno J., La persistência del Antiguo Régimen. Europa hasta la Grand Guerra (trad. do inglês), Madrid, Alianza Editorial, 1981. 
MENDES, José M. Amado, A História como Ciência. Fontes, Metodologia e Teorização, 3. a ed., Coimbra, Coimbra Editora, 1993. MENDES, José M. Amado, «A História na Faculdade de Letras da Universidade de Coimbra: Investigação e ensino (1911-1926)», Universidade(s). História. Memória. Perspectivas. Actas do Congresso "História da Universidade". (No 7. Centenário da sua Fundação). 5 a 9 de Março de 1990, vol. 1, Universidade de Coimbra, 1990, p. 477-498.

MENDES, José Amado, «Alberto Sampaio, precursor da história do presente», Boletim Cultural. Vila Nova de Famalicão, 3/4, III série, 2007/8, p. 415-426.

MUNSLOW, Alun, The future of history, Inglaterra-Estados Unidos, Palgrave Macmillan, 2010.

NUNES, João Paul Avelãs, A História Económica e Social na Faculdade de Letras da Universidade de Coimbra. 1911-1974, Lisboa, Instituto de Inovação Educacional/Ministério da Educação, 1995.

PERES, Damião (dir.), História de Portugal, Porto, 9 vols. (1 dos quais de índices e 1 suplemento), Livraria Civilização, 1928-1958; II Suplemento, de Franco Nogueira, 1981.

Repertório Bibliográfico da Historiografia Portuguesa. 1974-1994. Comissão Científica e Supervisora constituída por Maria Helena da Cruz Coelho, Maria Manuel Tavares Ribeiro e Joaquim Ramos de Carvalho, Coimbra, Faculdade de Letras da Universidade de Coimbr/Instituto Camões, 1995.

REVEL, Jacques, «Histoire et Sciences Sociales: les paradigmes des Annales», Annales. E. S. C., 34. ${ }^{\circ}$ ano, n. ${ }^{\circ}$ 61, 1991, p. 1360-1366.

RODRIGUES, Manuel Augusto, A Universidade de Coimbra no século XX. Actas da Faculdade de Letras, vol. I (1911-1925); vol. II (1925-1936), Publicações do Arquivo da Universidade de Coimbra, Coimbra, 1989-1991.

RODRIGUES, Manuel Augusto, «Da Faculdade de Teologia para a Faculdade de Letras da Universidade de Coimbra», Revista de História das Ideias, 11: Cultura, Política e Mentalidades, 1989, p. 517-542.

"Senado. Actas", 1933, Arquivo da Universidade de Coimbra (AUC).

STONE, Lawrence, «The Revival of Narrative: Reflections on a New Old History?», Past and Present, n. ${ }^{\circ} 85,1979$, p. 3-24.

"Sumários" de várias disciplinas de História, AUC. 
TORGAL, Luís Reis, História e ideologia, Coimbra, Minerva, 1989. TORGAL, Reis, MENDES, José Amado e CATROGA, Fernando, História da História em Portugal. Séculos XIX e XX, 2 vols., Lisboa, Temas \& Debates, 1998.

VAQUINHAS, «Estudos sobre as mulheres na área de História», História, ano XVIII (nova série), n. ${ }^{\circ} 18$, Março de 1996, p. 51-61.

VASCONCELOS, António de, «Dr. Porfírio da Silva», Revista da Universidade de Coimbra, vol. VIII, 1922, p. 613-614. 